cytoplasm. Two patients had vitiligo but neither had autoantibodies. None of the other patients had evidence of an autoimmune disorder or other disease known to be associated with an increased prevalence of the various antibodies studied.

The two patients with intrinsic factor antibody had normal haemoglobin $\left(13.6\right.$ and $15 \cdot 1 \mathrm{~g} / 100 \mathrm{ml}$ ) and serum vitamin $B_{12}$ levels $(280$ and $290 \mathrm{pg} / \mathrm{ml})$.

\section{Discussion}

These results indicate a significantly increased prevalence of autoantibodies against thyroid cytoplasm and gastric parietal cells in patients with lichen sclerosus when compared with control subjects. The presence or absence of these antibodies was not related to the severity or duration of the disease, suggesting that these autoantibodies did not arise as a consequence of lichen sclerosus. Though our control subjects were from Edinburgh and the patients with lichen sclerosus from Newcastle a regional difference in the prevalence of autoantibodies is an unlikely explanation, since the large differences found are outside the range previously reported from different centres (Ungar et al., 1968; Irvine et al., 1969; Irvine et al., 1970; Mathews et al., 1973).

Though the observation of two patients with lichen sclerosus and vitiligo led to the present study neither of the two patients with vitiligo had autoantibodies and no further patients with both conditions were found. In fact, the overall prevalence of vitiligo $(2 \cdot 6 \%)$ in lichen sclerosus as reported by Wallace
(1971) is probably not higher than in a normal population (Lerner, 1959).

Of the 10 patients with thyroid cytoplasmic antibodies only one had clinical thyroid disease though the rest may have had subclinical thyroiditis (Goudie et al., 1959). Two patients with parietal cell antibody also had increased titres of intrinsic factor antibody. The serum vitamin $B_{12}$ level in both patients was normal but they must be considered to be at risk of developing malabsorption of vitamin $\mathrm{B}_{12}$ at some time in the future. (Ardeman et al., 1966). These findings make it likely that the incidence of pernicious anaemia will be found to be increased in lichen sclerosus.

The increased prevalence of autoantibodies in lichen sclerosus suggests that the condition may be related to or caused by an autoimmune process.

\section{References}

Ardeman, S., et al. (1966). Quarterly fournal of Medicine, 35, 421. Bor, S., Feiwel, M., and Chanarin, I. (1969). British Fournal of Dermatology, 81, 83 .

Britt, R. P., et al. (1969). British Fournal of Haematology, 16, 457.

Cunliffe, W. J., et al. (1968). British fournal of Dermatology, 80, 135

Goudie, R. B., Anderson, J. R., and Gray, K. G. (1959). Fournal of Pathology and Bacteriology, 77, 389.

Irvine, W. J., Chan, M. W., and Scarth, L. (1969). Clinical and Experimental Immunology, 4, 489.

mental Immunology, 4, 489.
Irvine, W. J., et al. (1970). Lancet, 2, 163.

Lerner, A. B. (1959). Fournal of Investigative Dermatology, 32, 285.

Mathews, J. D., et al. (1973). Lancet, 2, 754

Mathews, J. D., et al. (1973). Lancet, 2,
Ungar, B., et al. (1968). Lancet, 2, 415 .

Wallace, H. J. (1971). Transactions of the St. Fohn's Hospital Dermatological Society, 57, 9.

\title{
Combined T and B Cell Acute Lymphoblastic Leukaemia
}

\author{
D. G. HAEGERT, J. C. CAWLEY, A. KARPAS, A. H. GOLDSTONE
}

British Medical fournal, 1974, 4, 79-82

\section{Summary}

A case of acute lymphoblastic leukaemia in a 17-year-old male is described. The patient had many distinctive features including a vēry high blast cell count, prominent lymphadenopathy and hepatosplenomegaly, thymic mass, and a fulminant clinical course. Immunological studies on the blast cells using a variety of techniques showed the presence of two distinct subpopulations, one having the surface characteristics of thymus-dependent ( $T$ ) lymphoid cells and the other those of bursa-equivalent (B) lymphoid cells. The case therefore represents the first example of a combined $T$ and $B$ cell acute leukaemia.

\section{Introduction}

It is now widely recognized that lymphocytes derived from human bone marrow (B lymphocytes) possess surface immunoglobulin determinants (Pernis et al., 1971; Hallberg et al., 1974), receptors for the Fc portion of fixed IgG (Brain

\footnotetext{
University of Cambridge, Addenbrook's Hospital, Cambridge CB2 $2 Q Q$

D. G. HAEGERT, M.D., F.R.C.P., Research Fellow, Department of Immunology

J. C. CAWLEY, M.B., PH.D., Research Fellow in Haematological Medicine A. KARPAS, PH.D., Assistant Director of Research in Haematological Medicine

A. H. GOLDSTONE, M.A., M.R.C.P., Senior Registrar, Department of Haematology
}

and Marston, 1973; Hallberg et al., 1973), and receptors for bound C3 (Bianco et al., 1970; Michlmayr and Huber, 1970). Thymus-derived lymphocytes (T lymphocytes), on the other hand, have an affinity for non-sensitized sheep red blood cells (Lay et al., 1971; Jondal et al., 1972). These surface markers have been examined by an ever increasing number of investigators in an attempt to characterize human lymphoid neoplasms as diseases of $T$ or $B$ lymphocyte origin. Results of studies of cases of acute lymphoblastic leukaemia (A.L.L.) have been variable. Whereas some studies have failed to show $\mathbf{T}$ or B markers in A.L.L. lymphoblasts (Lay et al., 1971; Wilson and Nossal, 1971; Shevach et al., 1972; Wybran et al., 1973, others have found a variable number of cases with $\mathrm{T}$ cell markers on the surface of the lymphoblast population (Borella and Sen, 1973; Chin et al., 1973; Kersey et al., 1973; McCaffrey et al., 1973; Seligmann et al., 1973; Belpomme et al., 1974; Catovsky et al., 1974 a).* Cases of A.L.L. of B cell origin have not been described.

We report here a unique case of A.L.L. with two neoplastic populations, one forming sheep red blood cell rosettes and the second expressing surface immunoglobulin determinants.

\section{Case Report}

A 17-year-old man presented with a two-week history of malaise, cervical lymphadenopathy, and a right facial weakness of sudden

*Since the writing of this paper a single example of B cell A.L.L. has been described in an elderly man (Gajl-Peczalska et al., 1974). 
onset. On examination he proved to have a right seventh cranial nerve palsy of lower motor neurone tvpe, generalized lymphadenopathy with prominent cervical node enlargement, a $10-\mathrm{cm}$ splenomegaly, and a $4-\mathrm{cm}$ hepatomegaly, but his general condition gave no cause for immediate concern. Blood count showed: haemoglobin $15.0 \mathrm{~g} / 100 \mathrm{ml}$, W.B.C. $450,000 / \mathrm{mm}^{3}$, and platelets $85,000 / \mathrm{mm}^{3}$. Differential white cell count showed that $92 \%$ of all leucocytes were bla:t cells and the remaining $8 \%$ were neutrophils and monocytes; normal small lymphocytes made up less than $1 \%$ of all cells. The cytology and cytochemistry of the primitive cells suggerted a diagnosis of A.L.L. Bone marrow aspirate was extensively infiltrated by more than $95 \%$ of similar leukaemic cells. Chest $x$-ray examination showed the presence of a large anterosuperior mediastinal mass. Levels of urea and electrolytes, measured on the second day in hospital, were normal, but serum calcium was raised at $12 \mathrm{mg} / 100 \mathrm{ml}$.

Treatment with vincristine $(2 \mathrm{mg})$, prednisone $(60 \mathrm{mg} /$ day $)$, and allopurinol was started on the second day. Apart from slight nausea, which was attributed to the hypercalcaemia, he remained reasonably well until the evening of the third day in hospital when his nausea became worse and he began to feel unwell. A few hours later his condition suddenly deteriorated and he collapsed and died before any medical attention was possible.

\section{Methods}

Peripheral blood and bone marrow smears were stained with May-Grünwald-Giemsa, Sudan black, and periodic-acid Schiff (P.A.S.), and routine cytochemical analysis was performed (Hayhoe and Flemans, 1969).

Peripheral blood $(20 \mathrm{ml})$ was sedimented with $1 \%$ methyl cellulose. The leucocyte-rich supernatant was washed three times with Hepes-buffered modified Eagle's medium (M.E.M.) then made up to a final suspension of $2.0 \times 10^{6} \mathrm{cells} / \mathrm{ml}$ in Hepes-M.E.M. with $0.2 \%$ bovine serum albumin.

\section{ROSETTE TESTS}

To detect lymphocytes with affinity for non-sensitized sheep erythrocytes a sheep red blood cell rosetting reaction was used. Fc receptors, C3 receptors, and immunoglobulin determinants were detected by the $\mathrm{Fc}, \mathrm{C} 3$, and mixed antiglobulin (M.A.G.) rosetting reactions respectively. Indicator red cells were prepared for each test as previously described (Haegert et al., 1974). As an antiglobulin reagent for the M.A.G. reaction rabbit antihuman IgM serum was raised to IgM preparations from two patients with Waldenström's macroglobulinaemia (Haegert et al., 1974). In each rosetting reaction four $20 \mu \mathrm{l}$ drops of lymphocytes were mixed in plastic precipitation tubes $(50 \times 4 \mathrm{~mm})$. Each test was set up in duplicate. In the sheep red blood cell rosetting reaction the tube was incubated for $15 \mathrm{~min}$ at $37^{\circ} \mathrm{C}$. then centrifuged at room temperature. The pellet was then immediately placed in ice and kept at $40^{\circ} \mathrm{C}$ for one hour before scoring. In the other rosetting reactions the lymphocyteindicator red cell mixtures were centrifuged immediately at $200 \mathrm{~g}$ for three minutes at room temperature and then immediately placed in ice and stored at $4^{\circ} \mathrm{C}$ for at least 30 minutes before scoring.

For scoring purposes cytocentrifuge preparations of the rosette tests were made by diluting the test suspensions to a total of $10^{6}$ cells (including erythrocytes) per $\mathrm{ml}$ with Hepes-M.E.M. Then $0.2 \mathrm{ml}$ of this preparation was loaded into each cytocentrifuge well with siliconized Pasteur pipettes and centrifuged at $200 \mathrm{~g}$ for five minutes. The slide preparations were then stained with Leishman's stain. In these preparations lymphoid cells forming rosettes with multiple red blood cells were easily identified. Nearby individual red blood cells did not constitute a definite rosette unless three or more of these red cells were clearly attached to the lymphoid cell.

Combined direct immunofluorescence and sheep red blood cell rosetting was used to exclude the presence of multiple
$B$ and $T$ markers on the same cell population. Fluoresceinelabelled polyvalent swine antihuman globulin (Nordic Pharmaceuticals) was used to stain viable lymphocytes by the direct method. Lymphocytes were incubated with the fluorescent antisera at $4^{\circ} \mathrm{C}$ for 30 minutes, washed three times in Hepes-M.E.M. containing $0.2 \%$ bovine serum albumin, then rosetted with either sheep red blood cells or Fc-bearing indicator cells (see above). Each cell was then viewed alternately under phase contrast and fluorescent illumination and scored for the presence of one, both, or neither markers.

In preparing the cell cultures used for the combined immunofluorescent/rosetting study heparinized whole blood was allowed to stand for two hours at room temperature, and white blood cells were then separated from the leucocyterich supernatant by slow speed centrifugation. The cell pellet was suspended in R.P.M.1-1640 medium supplemented with $20 \%$ fetal bovine serum and antibiotics. The cells were cultured at $37^{\circ} \mathrm{C}$ in $5 \% \mathrm{CO}_{2}$ in air and then harvested after two weeks for surface marker studies.

\section{Results}

\section{CYTOLOGY AND CYTOCHEMISTRY}

The cytology and cytochemistry of the blast cells were similar in both the peripheral blood and marrow. The primitive cels in general displayed a high nuclear:cytoplasmic ratio but were of variable size and shape, ranging in diameter from $7 \mu \mathrm{m}-18 \mu \mathrm{m}$. The nuclei usually contained a single nucleolus, and some displayed deep clefts; the scanty basophilic cytoplasm was agranular. The blast cells were completely unreactive in the Sudan black stain, while about $20 \%$ contained blocks or granules of P.A.S. positivity against a negative cytoplasmic background. Significant numbers of mitoses were present in both the peripheral blood and marrow, and it was not unusual to see two mitotic figures in any given high power field.

\section{ROSETTE TESTS AND IMMUNOFLUORESCENCE}

Surface marker studies of the peripheral blood lymphoblast population were performed in cytocentrifuge preparations which facilitated clear morphological recognition of the rosetting population. Romanowsky-stained preparations of the separated leucocytes showed a population similar to that of the peripheral blood. The lymphoid cells were composed of $99 \%$ lymphoblasts. It was apparent that two lymphoblast populations were present, $63 \%$ rosetting with sheep red blood cells and $41 \%$ with surface immunoglobulin determinants as detected by the M.A.G. reaction (see table). All of the lymphoblasts could be accounted for by the two $T$ and $\mathbf{B}$ markers.

Because of the early demise of the patient studies to ensure that $T$ and $B$ markers were on different populations of cells had to be performed on material put in culture at the time of diagnosis. Cultured cells were examined using direct immunofluorescence together with sheep or Fc-rosetting reactions. The major persisting population was immunoglobulin-bearing with an associated high percentage of Fcrosetting cells. A total of $90 \%$ of the Fc-bearing cells were also positive for immunoglobulin, $10 \%$ being negative for immunoglobulin. $8 \%$ of the persisting cells in culture formed sheep red blood cell rosettes and all of these were negative for immunoglobulin.

\section{NECROPSY}

Necropsy confirmed the presence of widespread lymphadenopathy and showed a greatly enlarged thymus (290 g). There was no macroscopic parotid infiltration and it was 
Surface Markers on Fresh A.L.L. Lymphoblasts and on Cultured Lymphoid Cells. Results expressed as Percentage of Cells reacting with Specific Indicator System

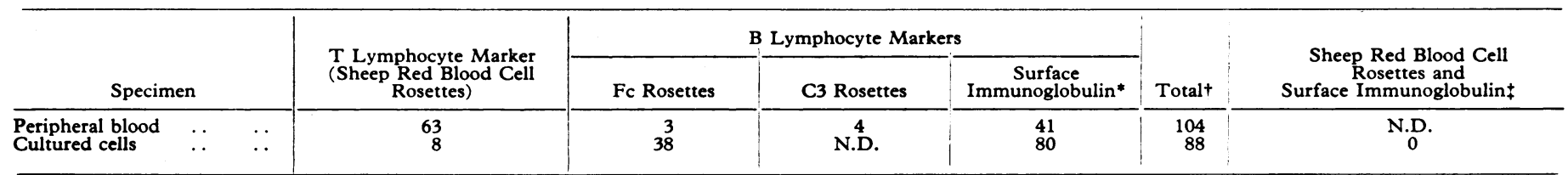

* Surface immunoglobulin determinants were detected by M.A.G. reaction (fresh peripheral blood) or direct immunofluorescence (cultured lymphoid cells).

+ Values represent sum of cells with $T$ marker and those with surface immunoglobulin determinants.

N.D. $=$ Not done

felt that pressure from the greatly enlarged cervical lymph nodes was the likely cause of this patient's facial nerve palsy. Both kidneys were found to contain several rounded $2-\mathrm{cm}$ tumours composed of lymphoid cells resembling those found in the peripheral blood and marrow. No other extranodal tumour masses were detected. No immediate cause of the patient's sudden death was found. In particular, there was no evidence of fulminating infection or intracranial haemorrhage. The probable cause of death was therefore thought to be an acute metabolic derangement caused by massive cell breakdown consequent upon chemotherapy (possibly hyperkalaemia, though we have no data to confirm this).

\section{Discussion}

Most normal peripheral blood lymphocytes can be subdivided into two distinct populations-namely, $T$ and $B$ (Raff, 1973). There are, however, small populations in normal people without readily detectable surface $T$ or $B$ markers and other small populations with combined $\mathbf{T}$ and $\mathbf{B}$ surface determinants (Dickler et al., 1974). Hence, one might expect to find human lymphoid neoplasms consisting of any one of these four cell types. In fact, examples of most of these have been described. Thus, chronic lymphocytic leukaemia (Seligmann et al., 1973), adult diffuse lymphocytic lymphomas (lymphosarcomas) (Aisenberg and Bloch, 1972), follicular lymphoma (Jaffe et al., 1974), and leukaemic reticuloendotheliosis (Catovsky et al., 1974 b) have all been found to show predominantly $B$ cell characteristics. In contrast, $T$ cell neoplasms appear to be less common. Examples include Sèzary's syndrome (Broome et al., 1973), some cases of prolymphocytic leukaemia (Catovsky et al., 1973), some cases of A.L.L. (Catovsky et al., 1974 a), and as yet isolated cases of chronic lymphocytic leukaemia (Lille et al., 1973). In addition, a case of an obscure lymphoproliferative disorder has recently been described with neoplastic cells having combined surface membrane features (Sandilands et al., 1974).

It is difficult to understand the significance of so-called null cell neoplasms-that is, neoplasms of cells without surface markers. Thus, many cases of A.L.L. have been described without detectable surface markers (Lay et al., 1971; Wilson and Nossal, 1971; Shevach, et al., 1972; Wybran et al., 1973). Though these could represent null cell neoplasms, a more probable interpretation is that the neoplastic cells represent a primitive population which has failed to express surface markers.

Immunological assessment of our case showed two distinct neoplastic populations, one with surface $T$ markers and the other with surface immunoglobulin determinants. Summation of the lymphoblasts with immunoglobulin determinants and those with affinity for sheep red blood cells accounted for all the cells. This distinguishes the present case from the lymphoproliferative disorder having combined $\mathrm{T}$ and $\mathrm{B}$ markers on the same cell (Sandilands et al., 1974). In the latter case the sum of sheep-rosetting cells and Fc-binding cells was much greater than $100 \%$ and there was a high percentage of cells with mixed Fc binding and shecp rosettes. Our patient's early demise precluded investigation for double markers on fresh peripheral blood lymphoblasts. Studies of cultured cells, however, indicated that a minor but separate $T$ cell population persisted in culture, and that these cells had no detectable surface immunoglobulin. Since cell lines obtained from normal subjects have $B$ cell characteristics (Minowada, 1973) our result suggests that the $\mathrm{T}$ cells in culture are neoplastic in origin. This suggests that in the original sample there were two separate neoplastic populations with predominant growth of the $\mathrm{B}$ cell population in culture.

In view of the high percentage of lymphoblasts with immunoglobulin determinants in the original peripheral blood sample it was perhaps unusual to find only small percentages of Fc- and C3-binding lymphoblasts. Most cases of chronic lymphocytic leukaemia (Haegert et al., 1974) and leukaemic reticuloendotheliosis (Catovsky et al., 1974 b), both B cell neoplasms, have variable but usually high percentages of neoplastic cells with $\mathrm{Fc}$ and $\mathrm{C} 3$ receptors. Therefore the significance of this finding in our patient is uncertain, but it is of interest to note that in culture a much higher percentage of the cells with immunoglobulin determinants also expressed $\mathrm{Fc}$ receptors (see table).

In addition, this case had distinct clinical featuresnamely, a combination of a leukaemia with a very high blast cell count, poor survival, prominent lymphadenopathy and hepatosplenomegaly, thymic mass, and "metastatic" nodules. Many of these features resemble those found in the $T$ cell acute leukaemias recently described by Catovsky et al. (1974 a) and they may thus reflect the high $\mathrm{T}$ cell component $(63 \%$ of 450,000 ) present in our patient.

Finally, the immunological significance of this unique case is conjectural. Whether it represents a neoplasm of primitive lymphoid cells which have differentiated into both $\mathbf{T}$ and $\mathbf{B}$ cells, or whether it represents the simultaneous or sequential development of two separate neoplastic populations remains uncertain.

We thank Professor F. G. J. Hayhoe for permission to publish details of this patient who was under his care. D.G.H. is supported by the M.R.C. of Canada, and J.C.C. and A.K. are in reoeipt of Leukaemia Research Foundation (U.K.) grants.

\section{References}

Aisenberg, A. C., and Bloch, K. J. (1972). New England fournal of Medicine,

287, 272.

Bianco, C., Patrick, R., and Nussenzweig, V. (1970). Fournal of Experimental Medicine, $132,702$.

Borella, L., and Sen, L. (1973). Journal of Immunology, 111, 1257.

Brain, P., and Marston, R. H. (1973). European fournal of Immunology, $3,6$.

Broome, J. D., et al., (1973). Clinical Immunology and Immunopathology, 1,319 .

Catovsky, D., et al. (1973). Lancet, 2, 232.

Catovsky, D., et al. (1974 a). British Medical fournal, 2, 643.

Catovsky, D., et al. (1974 b). British fournal of Haematology, 26, 29.

Chin, A. H., et al. (1973). Clinical Immunology and Immunopathology, $1,499$.

Dickler, H. B., Adkinson, N. F. jun., and Terry, W. D. (1974). Nature, 247, 213.

Gajl-Peczalska, K., et al., (1974). Clinical and Experimental Immunology, 17, 561 .

Haegert, D. G., Hallberg, T., and Coombs, R. R. A. (1974). International Archives of Allergy and Applied Immunology, 46, 525.

Hallberg, T., Gurner, B. W., and Coombs, R. R. A. (1973). International Archives of Allergy and Applied Immunology, 44, 500. 
Hallberg, T., et al. (1974). Fournal of Immunological Methods, 4, 317. Hayhoe, F. G. J., and Flemans, R. J., (1969). An Atlas of Haematological Cytology., London, Wolfe Medical Books.

Jaffe, E. S., et al. (1974). New England Fournal of Medicine, 290, 813 Jondal, M., Holm, G., and Wigzell, H. (1972). Fournal of Experimental Medicine, 136, 207.

Kersey, J. H., et al., (1973). Science, 182, 1355.

Lay, W. H., et al. (1971). Nature, 230, 531.

Lille, I., et al. (1973). Lancet, 2, 263.

McCaffrey, R., Smoler, D. F., and Baltimore, D. (1973). Workshop on Prognostic Factors in Human Acute Leukaemia, Schloss Reisenberg, Ulm.
Michlmayr, G., and Huber, H. (1970). Fournal of Immunology, 105, 670. Minowada, J., Ohnuma, T., and Moore, G. E. (1973). Fournal of the National

Cancer Inststute, 49, 891 .
Pernis, B., et al. (1971). In Progress in Immunology, ed. B. Amos, p. 96., New York, Academic Press.

Raff, M. C. (1973). Nature, 242, 19.

Sandilands, G. P., et al. (1974). Lancet, 1, 903.

Seligmann, M., Preud'Homme, J-L., and Brouet, J-C. (1973). Transplantation Review, 16, 85.

Shevach, E. M., et al. (1972). Journal of Clinical Investigation, 51, 1933.

Wilson, J. D., and Nossal, G. J. V. (1971). Lancet, 2, 788.

Wybran, J., Chantler, S., and Fudenberg, H. (1973). Lancet, 1, 126.

\section{MEDICAL MEMORANDA}

\section{Caecal Rupture in Psychotic Patients}

\author{
M. MCCORMACK
}

British Medical fournal, 1974, 4, 82-83

Megacolon in psychotic patients has been sporadically documented, mainly by American workers. The details of two patients seen in this department within a short time of one another are given below; they had the additional unusual complication of ruptured caecum.

\section{Case 1}

An 82-year-old man had been admitted to hospital because of chronic schizophrenia for 42 years. Drug treatment was minimal but included benztropine $2 \mathrm{mg}$ daily. Over a period of four days he developed recurrent vomiting, and a diagnosis of subacute intestinal obstruction due to gross constipation was made. An enema was given with satisfactory result. Obstructive signs did not remit, however, and he was transferred to a general surgical ward. On examination he was dehydrated, had generalized abdominal tenderness, and an empty rectum on digital examination. Nasogastric suction and intravenous fluid replacement were started, and radiographical examination showed subdiaphragmatic gas. He died before laparotomy could be performed.

Necropsy showed a faecal peritonitis with a dilated ileum. The caecum was grossly distended, paper-thin, and had a medial perforation of $3 \mathrm{~cm}$ in diameter. The transverse and descending colon were also dilated, but most of the sigmoid and all of the rectum were empty. The colonic contents were soft throughout. Histological examination showed normal ganglion cells at all levels of the colon and anal canal.

\section{Case 2}

A 79-year-old woman with a 13-year history of depressive illness necessitating inpatient treatment developed alternating diarrhoea and constipation over a period of one month. Digital examination showed an empty rectum, but in view of her continued symptoms and a palpably enlarged colon numerous enemas and laxatives were given over several days with poor results. Her clinical condition deteriorated and she was admitted to a general medical ward. The diagnosis of large bowel obstruction was confirmed clinically, and in spite of further repeated attempts at evacuation by enema she developed acute pulmonary oedema, tachycardia, and hypotension, and she died soon aftemwards.

\footnotetext{
Department of Pathology, University of Aberdeen, Aberdeen AB9 2ZD

M. MCCORMACK M.B. CH.B. Lecturer
}

At necropsy the colon was grossly dilated throughout its length, the anal canal alone being unaffected. The caecum was especially distended and thinned, and there was a slit-like $1 \mathrm{~cm}$ anterior perforation with a faecal peritonitis. The faeces were soft and foamy and there was no organic obstruction. As in case 1 ganglion cells were present at all levels of the large bowel and anal passage.

\section{Comment}

Megacolon has previously been noted in both psychoses (Ehrentheil and Wells, 1955) and Parkinson's disease (Lewitan et al., 1951). The aetiology is not clear but in Parkinson's disease anticholinergic drugs may be a factor. The patient in case 1 had been taking an anticholinergic agent (benztropine) for a considerable period up to the time of his admission to a surgical ward, but there was no such history in case 2 . Chlorpromazine has been incriminated as a rare cause of severe constipation (Oettinger, 1958), and Zimmerman (1962) was able to produce an animal model with striking similarities to the human syndrome by the intraperitoneal injection of large doses of this drug in rats. Though both patients reported here had chlorpromazine at some time during their illnesses neither had ingested the drug in large amounts or for a prolonged period before the appearance of gastrointestinal symptoms. Since iatrogenic causes now seem to be unlikely it is probable that most cases of megacolon are essentially psychiatric in origin, as proposed by Ehrentheil and Wells (1955).

Whatever the cause these patients have soft faeces and markedly decreased bowel and sphincter tonus, and evacuation, either by enema or spontaneously, is difficult or ineffective. Such are the difficulties in management that Watkins and Oliver (1965) have recommended subtotal colectomy, apparently with gratifying results.

No cases previously described have developed caecal rupture though this is the most distensible part of the colon with a bursting pressure of about $50 \mathrm{~mm} \mathrm{Hg}$ in the normal viscus (Burt, 1931). Noveroske (1972) confirmed this and pointed out that, as with all distensible tubes, the colon must obey the law of Laplace. It follows that a caecum which is already distended and thinned will tolerate a proportionately smaller increase in intraluminal pressure before splitting, and it is significant that both these patients had enemas, multiple in one case, with inevitable increase in intraluminal pressure immediately before sudden physical deterioration.

It seems, therefore, that colonic rupture must take a place alongside the other often forgotten dangers of enema, which include chemical colitis (Hirschman, 1927; Barker, 1945; Pike et al., 1971), anaphylactoid reaction (Smith, 1967; Egdell and Johnson, 1973), and direct traumatic damage (Bendit, 1945). It is extremely unlikely that this complication is as rare as its absence from the literature suggests. Megacolon in psychotics is relatively common, but necropsy in mental hospital patients is not as a rule routine. Awareness of the condition and an 